University of Nebraska - Lincoln

DigitalCommons@University of Nebraska - Lincoln

1997

\title{
Evidence for Natural Biological Control: Insects Decrease Survival and Growth of a Native Thistle
}

John A. Guretzky

University of Nebraska - Lincoln, jguretzky2@unl.edu

Svata M. Louda

University of Nebraska - Lincoln, slouda1@unl.edu

Follow this and additional works at: https://digitalcommons.unl.edu/bioscilouda

Part of the Ecology and Evolutionary Biology Commons

Guretzky, John A. and Louda, Svata M., "Evidence for Natural Biological Control: Insects Decrease Survival and Growth of a Native Thistle" (1997). Svata M. Louda Publications. 8.

https://digitalcommons.unl.edu/bioscilouda/8

This Article is brought to you for free and open access by the Papers in the Biological Sciences at DigitalCommons@University of Nebraska - Lincoln. It has been accepted for inclusion in Svata M. Louda Publications by an authorized administrator of DigitalCommons@University of Nebraska - Lincoln. 


\title{
EVIDENCE FOR NATURAL BIOLOGICAL CONTROL: INSECTS DECREASE SURVIVAL AND GROWTH OF A NATIVE THISTLE
}

\author{
John A. GuretzKY AND SvaŤA M. LOUdA ${ }^{1}$ \\ School of Biological Sciences, University of Nebraska, Lincoln, Nebraska 68588-0118 USA
}

\begin{abstract}
Native thistles, in contrast to exotic species, are seldom noxious weeds. In this study, we evaluated one hypothesis for this difference: that the growth and fitness of native thistles are limited by natural enemies. Specifically, we tested the effect of insect foliage feeding on the survival and growth of large and small rosettes of tall thistle, Cirsium altissimum, using an insecticide exclusion experiment. Large juveniles were proportionally more damaged than were small ones. Insecticide reduced insect feeding, including overall intensity of plant damage and area removed or damaged on each of the two longest leaves, compared to controls treated only with water. As a result, both leaf growth and plant size increased significantly by the end of the growing season. Growth parameters showing major increases with the reduction in insect herbivory included upper rootcrown diameter, the total number of leaves, and the length of the two longest leaves on both large and small rosettes. Insecticide also reduced the mortality of large juveniles to half that of the controls. Thus, the study shows that the suite of naturally occurring, coevolved, foliage-feeding insects significantly reduces the growth and survival of rosettes of this native thistle under field conditions. The results provide strong support for the hypothesis underlying biological control of weeds programs.
\end{abstract}

Key words: biological control; Cirsium altissimum; insect herbivory; plant growth; plant survival; tall thistle; weed control.

\section{INTRODUCTION}

Classical biological control of weeds is based on the premise that feeding by specialized, herbivorous insects contributes significantly to preventing the proliferation and spread of potentially weedy plants within their native range (DeBach and Rosen 1991, Harley and Forno 1992, Blossey 1995). The classical strategy thus depends on the hypothesis that reestablishment of natural enemies will limit the density of exotic weeds. However, experimental data demonstrating that insects limit the growth, survival, and population density of potentially weedy plants under indigenous conditions are rare (Forsyth and Watson 1985, Crawley 1989, Louda and Rodman 1996).

Studies evaluating the effect of insect feeding on plant growth have generally examined the impact on large, established plants (reviews by Crawley 1988, Hendrix 1988, and Weis and Berenbaum 1989). These studies show that insects have the potential to affect plant performance. Documented effects include both changes in morphology (e.g., Louda 1984, Whitham and Mopper 1985) and reductions in growth, flowering, and seed production (e.g., Rausher and Feeny 1980, McEvoy et al. 1991, 1993, Doak 1992, Meyer and Root 1993, Ehrlen 1995a, $b$ ). The few field experiments that directly evaluate insect feeding effects on demographic

Manuscript received 22 July 1996; revised 14 February 1997; accepted 25 February 1997; final version received 19 March 1997.

${ }^{1}$ Send reprint requests to this author. parameters of weedy native plants also suggest a negative impact, i.e., for Rumex spp. (Whittaker 1982), tansy ragwort, Senecio jacobaea (Prins et al. 1989), thistles such as Cirsium canescens (Louda et al. 1990, Louda and Potvin 1995), the crucifer Cardamine cordifolia (Louda 1984, Louda and Rodman 1996), and several successional plants (Waloff and Richards 1977, Brown et al. 1988, Mills and Kummerow 1989). Some evidence also suggests that the lifetime fitness and density of short-lived perennials can be reduced and limited by insect herbivory (Louda 1982a, b, 1983, Doak 1992, Louda and Potvin 1995, Louda and Rodman 1996).

Although most observed effects are negative (Bergelson and Crawley 1992, Belsky et al. 1993), compensatory plant growth may mitigate or reverse the negative effects of herbivore feeding (van der Meijden et al. 1988, Verkaar 1988, Myers et al. 1990, Whitham et al. 1991, Matches 1992). Thus, the significance of insect feeding for plant population growth and density remains controversial (Crawley 1989, Louda 1989, 1995), especially for weedy species within their native ranges. We still lack comprehensive information on suppression vs. compensation of weedy species in response to insect feeding, especially on young plants (Harper 1977, Louda 1984). Yet the few studies of insect herbivory on survival and growth of the juveniles of native plants show that the interaction can be both intense and potentially important in plant population dynamics (e.g., Fye 1982, Whittaker 1982, Mills 1984, Zammit and Westoby 1988). 
Prediction of the effect of natural 'enemies on plant density and weediness clearly requires further studies to quantify interactions and responses to defoliation, especially for effects on survival and growth early in the life cycle (Harper 1977, Louda 1989). The case for increased investment in programs for the biological control of weeds needs more direct evidence of natural enemy effects under the indigenous conditions within the plants' native range. The purpose of the experiment reported here was to assess the extent of insect feeding and its impact upon rosettes of tall thistle, Cirsium altissimum (L.) Spreng. (Asteraceae), a native species in the western tallgrass region of the upper Great Plains. This system provides a good model for studying the role of natural enemies in the dynamics of potentially weedy species. Life history, phenology, and local distribution of this native thistle are similar to those of many exotic invasive thistles. Yet plant densities are seldom high, and the plant is not considered noxious. The results should be directly applicable to the assessment of biological control as a weed management strategy for invasive thistles (Louda and Masters 1993).

In this study, we addressed four questions about herbivory on the young plants in a population of tall thistle. First, how much leaf damage do insects impose? Second, does loss of leaf area influence juvenile survival, leaf growth, or seasonal increment in rosette size? Third, does feeding vary between the two main size classes of juveniles? Fourth, does compensatory regrowth eliminate the negative effects of leaf or plant damage by insects, and is the response related to size? Answers to these questions are needed to evaluate both the effect of the natural suite of insect enemies on plant performance, and the hypothesis that they contribute to limiting the weediness of native thistles.

\section{Methods}

\section{Study system}

Tall thistle, Cirsium altissimum, is a native monocarpic species that occurs throughout eastern Nebraska. It is occasionally common on roadsides, in pastures, and on moderately disturbed, noncultivated land. Rosettes initiate growth in early spring, and flowering plant density is related to juvenile density. While tall thistle is described as a biennial, our observations suggest that it can remain in the juvenile phase for a variable number of years prior to flowering. Plants typically develop flower heads in late July, and they set seed in August and September (Great Plains Flora Association 1986).

Insect herbivory is often evident, and many phytophagous insects have been collected feeding on the foliage or within the flowerheads of tall thistle. These insects include a curculionid weevil, Baris subsimilis Casey; two species of tephritid flies, Paracantha culta (Wiedeman), and an unknown species; and several microlepidopterans, including members of the Gelechi- dae, Pterophoridae, and Pyralidae, as well as grasshopper nymphs. Most of the species consistently present belonged to genera typical of thistle-feeding insects (Lamp and McCarty 1979, 1982). The herbivory assessed here was done by the entire leaf-feeding insect guild.

We conducted this study in a 2-ha field located at the Wagner Substation of the Lincoln Electric System, $6 \mathrm{~km}$ east of Lincoln, Nebraska (Section 17, Township 9N, Range 8E, Lancaster County, Nebraska), from 2 May to 19 September 1995. The field slopes gently $\left(<2^{\circ}\right)$ to the south. The site, which was graded $\sim 15 \mathrm{yr}$ ago, was mowed annually until 1989 . Subsequent management has involved only hand removal of invading trees and noxious weeds. Although the field is dominated by smooth brome (Bromus inermis Leyss. subsp. inermis), an alien grass, many native tallgrass prairie species, including goldenrod (Solidago canadensis L.), are recolonizing. Tall thistle was dispersed in patches throughout the field, especially in the southern, moister end. The 1995 growing season was marked by unusually cool, wet weather throughout May, which was then followed by exceptionally high temperatures and low rainfall in August and September (data are from the High Plains Climate Center, University of Nebraska, 1995).

\section{Experimental design}

As a mechanism to distribute the experimental test over the environmental variation present, we arbitrarily established three $2 \times 4 \mathrm{~m}$ blocks in the middle and southern portions of the field early in the growing season (2-9 May 1995). Blocks within the field were 40 $\mathrm{m}$ apart on average. In each block, we measured the basal diameter of all tall thistle rosettes. Density of juvenile thistles varied: $3.9,6.8$, and 3.1 juveniles per square meter per block. Based on previous observations of the age-size structure in the population, we divided the thistle rosettes within each block into two size classes: large, older rosettes $(>4.0 \mathrm{~mm}$ initial basal diameter, $N=31,28$, and 22 per block), and small, newer rosettes $(2.0-4.0 \mathrm{~mm}, N=21,26$, and 3 per block). Rosettes in the large size class were significantly bigger than those in the small size class at the beginning of the experiment ( $t$ test, $P<0.001$ ).

Rosettes in each size class within a block were randomly assigned to one of two treatments. In Treatment 1 , we sprayed plants with insecticide dissolved in water. We applied one of two insecticides at the recommended rate. Initially, we used Isotox (8\% "Acephate": O,Sdimethyl acetylphosphoramido-thioate, plus $2 \%$ "Hexakis": (2-methyl-2-phenylpropyl)-distannoxane: Chevron Chemical Corporation, Richmond, California). Since Isotox did not exclude insects completely, we used Diazinon (25\% 0-0-diethyl 0-(2-isopropyl-6-methyl-4-pyrimidinyl) phosphorothioate: Dragon Corporation, Roanoke, Virginia) instead from 4 July to 8 August 1995. However, control of insect feeding was even worse with 
Diazinon. Consequently, we used Isotox on the last two applications, 12 and 24 August 1995. Isotox has shown no growth stimulation in previous studies (Louda 1982a, $b, 1983$, Louda et al. 1990). In Treatment 2, we sprayed an equivalent amount of water on control plants. Treatments were applied using a hand sprayer. Treatment began 2-9 May 1995, continued weekly for two weeks, and then occurred biweekly through 24 August 1995.

\section{Measurements and analysis}

Field measurements were taken initially (2-9 May $1995)$ and then repeated four times after treatment was started: 23-25 May 1995, and then subsequently at $\sim 4$-wk intervals, ending 16 September 1995. Response variables included (1) basal diameter/upper rootcrown of the rosette, (2) total number of green leaves, (3) total number of dead leaves, (4) length of the longest leaf, (5) area damaged or removed by insects on the measured leaf, (6) total number of green leaves with evidence of insect feeding, and (7) overall plant damage intensity score. Measurement of the second-longest leaf was added later (21 July 1995) to verify estimates of leaf area lost from one leaf. Dead leaves were counted and then removed. Plant size was estimated by basal diameter of the rosette, measured by clamping calipers tightly around the central part of each rosette at the ground surface. This procedure avoided excavation of the plants during the growing season, but included a variable number of petioles. In the analysis, we partitioned the relative contribution of leaf bases to basal diameter by assuming that this contribution is proportional to the average number of leaves present. Leaf area removed or damaged on the two longest leaves at each sampling date was quantified by comparison against a $1-\mathrm{mm}^{2}$ grid. We scored the overall intensity of insect feeding damage to a plant from zero to 5 for each rosette: $0=$ no damage, $1=<0.5$ of leaves with $<10 \%$ of area gone or damaged by insects, $2=$ between 0.5 and 0.67 of leaves with $10 \%$ leaf area damaged, 3 $=$ between 0.67 and 0.75 of leaves with $>10 \%$ leaf area damage, $4=$ between 0.75 and 1.00 of leaves with $>10 \%$ area damage, and $5=$ most to all leaves with $>20-25 \%$ leaf area damaged.

To calculate the proportion of total leaf area damaged, we used field measurements of leaf length and leaf area removed, and an estimate of total leaf area per leaf based on a regression of square-root transformed leaf area ( $A$, in square centimeters) on leaf length ( $L$, in centimeters). The regression was developed using a set of leaves collected from nearby nonexperimental plants $(N=38$ leaves $)$. It was

$$
\begin{gathered}
A=0.648+0.240 L \\
\left(R^{2}=0.901, F_{1,37}=336.57, P<0.001\right) .
\end{gathered}
$$

The field data were analyzed using four-way repeated-measures analysis of variance, to establish main and interaction effects for treatment, size class, and sampling date for three blocks, for all plants that survived throughout the experiment $(N=16$ and 14 small rosettes, and 13 and 17 large rosettes, in water-control and insecticide treatments, respectively). This approach was a compromise, given the differential mortality that occurred among treatments. It is a conservative evaluation that underestimates the difference between treatments. All scores, counts, areas, and size data were square-root transformed prior to analysis. A priori hypotheses were tested using orthogonal contrasts (Wilkinson 1986).

\section{RESULTS \\ Insect herbivory}

On control plants, which had natural levels of insect feeding, area lost from the longest leaves averaged $8.8 \%$ on small rosettes and $21.3 \%$ on large rosettes over the season. The loss was higher than expected for the large rosettes, since 5-10\% loss is considered typical for temperate plants (Crawley 1983). The range in average leaf area lost for controls varied from a low of $6 \%$ on 18 August 1995 for the small rosettes to a high of $32 \%$ on 26 May 1995 for the large ones (Fig. 1A, B). Both the proportion of leaf area lost (Fig. 1) and the average damage per plant (Fig. 2) were generally higher on large rosettes than on small ones.

Insecticide significantly reduced insect feeding damage (Table 1; four-way ANOVA). Both the average intensity of plant damage (Fig. 2A, B; $P<0.001$ ) and the proportion of area damaged decreased on the longest (Fig. 1A, B; $P<0.001$ ) and on the second-longest (Fig. 1C, D; $P<0.001$ ) leaves.

The reduction in feeding with insecticide treatment was particularly striking for the large juveniles (Figs. $1 \mathrm{~B}$ and $2 \mathrm{~B}$ ). Large size in early season significantly increased the number of leaves damaged $(P<0.001)$, the average level of damage to a plant $(P<0.001)$, and the proportion of leaf area damaged on the longest leaf $(P<0.04$; Table 1$)$.

The significant increase in the level of damage between sampling dates was not surprising, since leaf damage often accumulates. The parameters that increased significantly were the number of leaves damaged $\left(F_{1,293}=15.07\right)$, the average level of damage to a plant $\left(F_{1,293}=6.41\right)$, and the proportion of area damaged on the second-longest leaf $\left(F_{1,142}=6.32\right.$; Table $1)$. The same trend was also clear, but not significant, for the longest leaf $(P=0.054)$.

Finally, two parameters of plant response to insecticide treatment varied significantly between blocks: the average level of plant damage $\left(F_{2,293}=8.19, P<\right.$ 0.001 ), and the damage to the longest leaf on each sampling date $\left(F_{2,293}=3.90, P=0.021\right.$; Table 1$)$.

Several significant and potentially interesting interactions also occurred in the determination of the level of insect feeding (Table 1). Treatment and size interacted to influence both the average level of damage to 

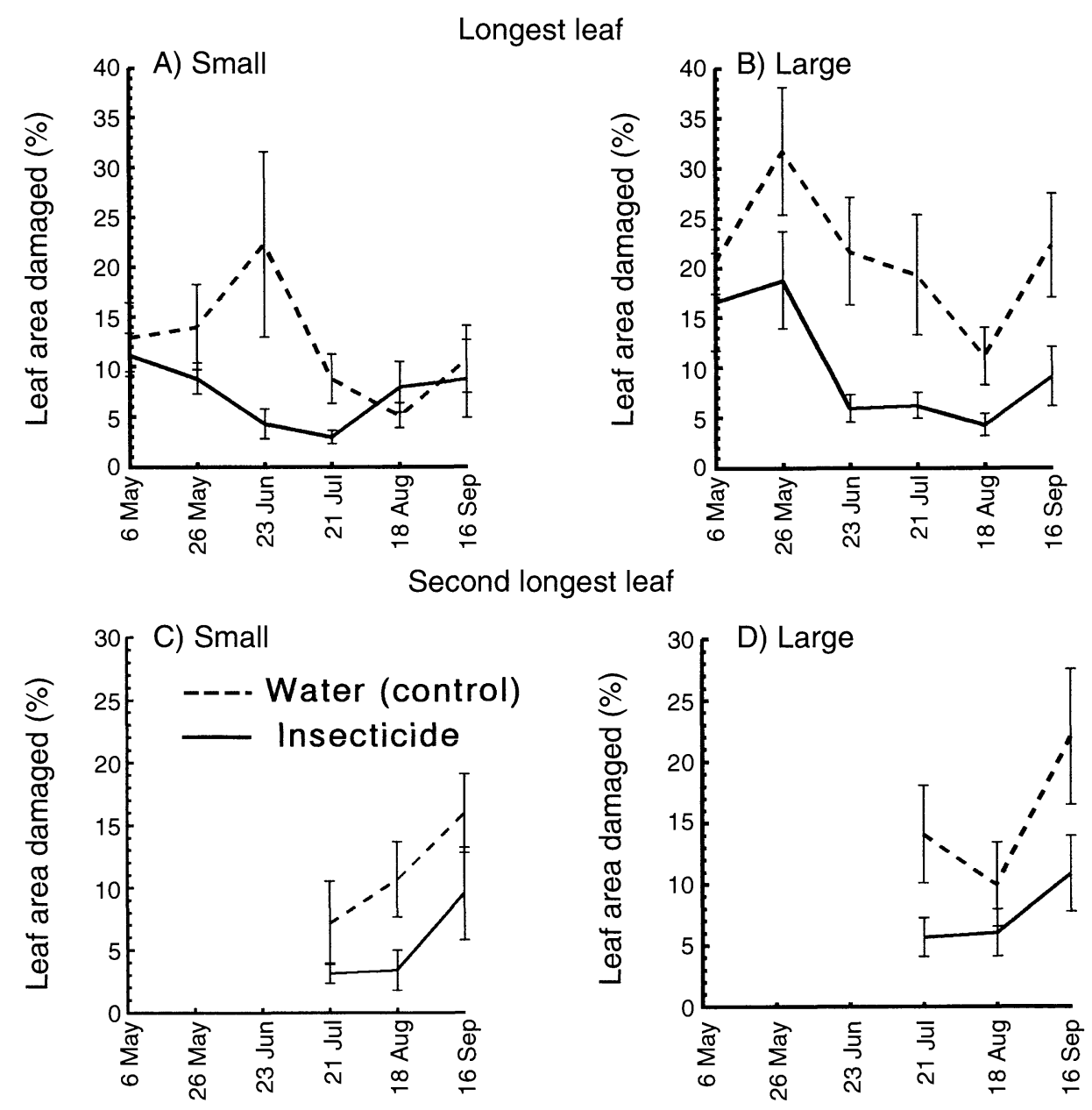

FIG. 1. Mean ( $\pm 1 \mathrm{SE})$ leaf area removed or damaged by insects (percentage of total leaf area) in insecticide and wateronly treatments, by leaf length for both small $(<4.0 \mathrm{~mm}$ initial basal diameter) and large $(\geq 4.0 \mathrm{~mm}$ initial basal diameter rosettes of tall thistle (Cirsium altissimum) on each sampling date in 1995: (A) longest leaf on small rosettes, (B) longest leaf on large rosettes, (C) second-longest leaf on small rosettes (added measurement, starting 21 July 1995), and (D) secondlongest leaf on large rosettes (added measurement, starting 21 July 1995). The insecticide treatment reduced damage significantly $(P<0.001)$ in four-way repeated-measures ANOVA on plants that survived during the experiment $(N=16$ and 14 small rosettes, plus 13 and 17 large rosettes; in water-control and insecticide treatments, respectively) on both longest $\left(F_{1,293}=10.38\right)$ and second-longest $\left(F_{1,142}=10.60\right)$ leaves. Size also had a significant influence $(P<0.001)$ on the number of leaves damaged $\left(F_{1,293}=37.73\right)$ and on the average level of damage $\left(F_{1,293}=10.94\right)$, as well as on each of the longest leaves $(P<0.04)$.

a plant $\left(F_{1,293}=6.46, P=0.012\right)$ and the leaf area damaged on the second-longest leaf $\left(F_{1,142}=3.92, P\right.$ $<0.05)$. This outcome reflects the fact that large plants were proportionately more damaged than small ones in both treatments (Fig. 1). Treatment and block interacted in the determination of the proportion of leaf area damaged on the second-longest leaf $\left(F_{1,142}=6.00, P<\right.$ $0.003)$. This result is consistent with the significant difference in the average level of damage among blocks (Table 1). An interaction between treatment and block may also have influenced both the average intensity of damage per plant $(P=0.074)$ and the proportion damaged on the longest leaf $(P=0.068)$. Size class interacted with date to affect the number of leaves damaged $\left(F_{4,293}=6.56, P<0.001\right)$. No four-way interaction was significant. These results show that the larger rosettes were more vulnerable to heavy insect feeding.

Thus, the insecticide treatment had three major outcomes, involving both main and interaction effects. First, insecticide significantly reduced evidence of insect feeding (Figs. 1 and 2). Second, early-season plant size was important in determining the level of herbivory, with large plants having proportionately higher levels of damage (Figs. 1 and 2). And third, spatial environmental heterogeneity led to significant variations in the average level of feeding on plants and in the damage to the longest leaf among blocks (Table 1).

Temporal variation in insect feeding occurred, and showed two patterns. First, treatment differences showed up rapidly (26 May 1995), peaked from late 

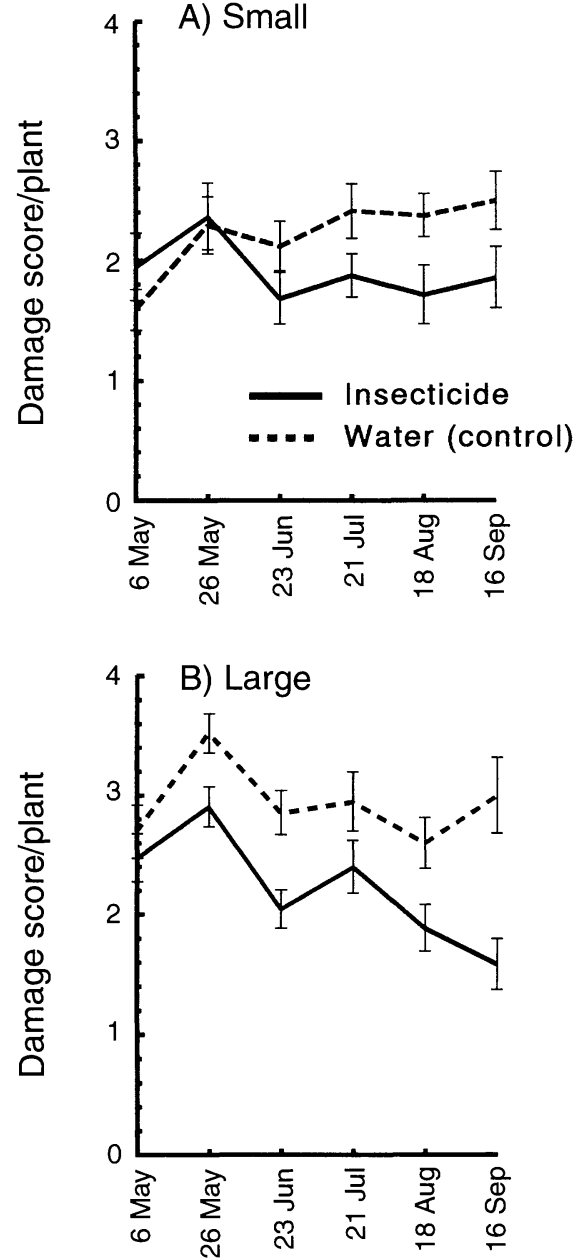

FIG. 2. Mean ( $\pm 1 \mathrm{SE})$ score for intensity of insect feeding for each rosette as a whole in insecticide and water-only treatments for small (A) and large (B) size class rosettes of tall thistle (Cirsium altissimum) on each sampling date in 1995. The insecticide effect was significant $\left(F_{4,293}=15.07, P<\right.$ $0.001)$.

June to late July, possibly declined in August, and rose again by September (Fig. 1). Differences in the proportion of leaf area damaged in the insecticide (compared to the control) treatment were consistent for both leaves measured. After the initial measurement and start of the experiment (6-15 May 1995), the difference between treatments was consistent for both leaves on large juveniles (Fig. 1B, D), except on 18 August 1995, and for the second-longest leaf on small juveniles (Fig. 1C). As the season progressed, leaves aged and accumulated damage. Marked leaves often died prior to the next date. Thus, some of the variation in leaf damage reflects the fact that, due to leaf mortality, different leaves were longest on successive dates.

Second, the pattern between treatments was similar for whole plant damage. The effect of treatment on average intensity of plant damage established rapidly, within 2-3 wk for large juveniles and 4-5 wk for small juveniles (Fig. 2A, B), and persisted through the remaining 15 (and 13) wk of the season. Furthermore, for large rosettes the damage score for insecticide-treated plants declined significantly over time, from 26 May to 16 September 1995 (Fig. 2B), suggesting cumulative effectiveness of the exclusion treatment.

\section{Plant response}

Insecticide treatment halved the mortality rate of large rosettes. Reduction of insect feeding significantly decreased the proportion dying, from $36.8 \%$ for controls to $15.2 \%$ for insecticide-treated rosettes $\left(\chi^{2}{ }_{1}=\right.$ 4.62, $P<0.05$ ). However, insecticide treatment did not significantly alter survival for small rosettes $\left(\chi^{2}{ }_{1}=\right.$ $2.56, P>0.05)$. Since survivorship from seedling to flowering year is cumulative, and since survivorship of large juveniles was decreased significantly (from 0.864 to 0.649 ), mortality due to insect feeding reduced the probability of maturing by at least $21.5 \%$.

Insecticide reduction of insect feeding also led to a significant increase in growth $(P<0.001)$ by the two longest leaves (treatment: longest leaf, $F_{1,293}=11.62$; second-longest leaf, $F_{1,142}=33.66$; Table 1). Rosettes treated with insecticide had significantly longer leaves on average than did those treated only with water (Fig. $3 \mathrm{~A}, \mathrm{~B})$. Length of the longest leaf on any date was also influenced $(P<0.001)$ by size $\left(F_{1,293}=36.65\right)$ and date $\left(F_{4,293}=10.20\right)$. Interestingly, interactions also occurred between treatment and date $(P<0.01)$ and between size class and block within the site $(P<0.01)$. Length of the longest leaf on both small and large rosettes increased from early to mid-May to 23 June 1995, with no difference between treatments. However, by 21 July 1995 the treatments had diverged, and the leaves on insecticide-treated juveniles were longer than those on water-treated rosettes in both size classes (Fig. $3 \mathrm{~A}, \mathrm{~B})$. Length of the second-longest leaf was influenced by size class $(P<0.01)$ and by date $(P<0.037)$, as well as by treatment (Fig. 3C, D). No interactions were required to explain the differences in length of the second-longest leaf (Table 1). Thus, protected leaves grew longer on average than did unprotected ones (Fig. 3). A significant, nonlinear pattern also appeared in the length of the longest leaf over the season (Fig. 3A, B), illustrating the spring-early summer growth phenology of the young plants.

By the end of the growing season, the significant insecticide reduction of leaf area removed by leaf-feeding insects (Table 1) led to a significant increase in plant size, measured both by the total number of green leaves (Table 2) and by the basal diameter of the rosette (Fig. 4). Reduction of insect-feeding damage by insecticide treatment also led to a general and significant increase in the total number of leaves per plant (Table $1, F_{1,293}=7.17$ ). The greater number of leaves in the insecticide treatment is also consistent with the hypothesis that no insecticide toxicity occurred. Large plants had more leaves $(P<0.001)$, as expected. And 
TABLE 1. Summary of all major differences in insect feeding and subsequent plant growth in insecticide and water-only control treatments.

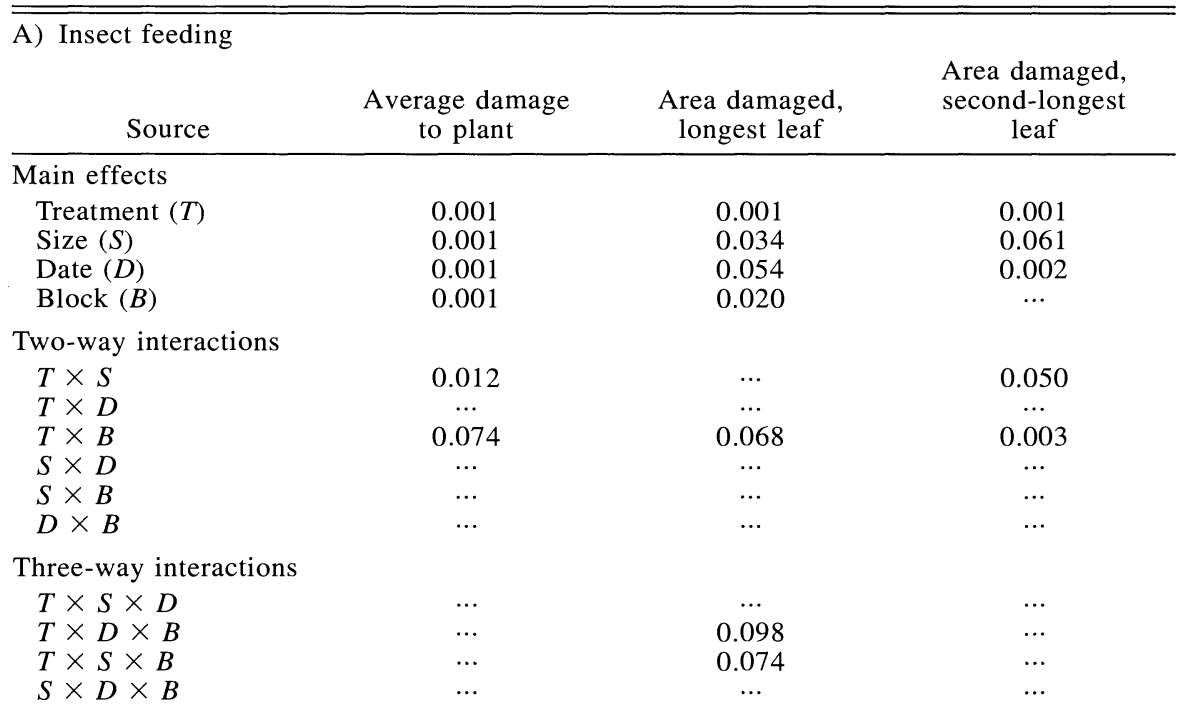

B) Plant growth

\begin{tabular}{|c|c|c|c|c|c|}
\hline Source & $\begin{array}{l}\text { Rootcrown } \\
\text { diameter }\end{array}$ & $\begin{array}{l}\text { Total no. } \\
\text { leaves } \\
\text { per plant }\end{array}$ & $\begin{array}{c}\text { Dead leaves } \\
\text { per plant }\end{array}$ & $\begin{array}{l}\text { Length, } \\
\text { longest } \\
\text { leaf }\end{array}$ & $\begin{array}{l}\text { Length, } \\
\text { second- } \\
\text { longest } \\
\text { leaf }\end{array}$ \\
\hline \multicolumn{6}{|l|}{ Main effects } \\
\hline Treatment $(T)$ & 0.001 & 0.008 & $\ldots$ & 0.001 & 0.001 \\
\hline Size $(S)$ & 0.001 & 0.001 & 0.001 & 0.001 & 0.009 \\
\hline Date $(D)$ & 0.026 & 0.001 & 0.001 & 0.001 & 0.037 \\
\hline Block $(B)$ & 0.066 & $\cdots$ & $\cdots$ & $\cdots$ & $\cdots$ \\
\hline \multicolumn{6}{|c|}{ Two-way interactions } \\
\hline$T \times S$ & $\ldots$ & $\ldots$ & $\ldots$ & $\ldots$ & $\ldots$ \\
\hline$T \times D$ & $\ldots$ & $\ldots$ & $\ldots$ & 0.005 & $\ldots$ \\
\hline$T \times B$ & $\ldots$ & $\ldots$ & $\ldots$ & $\ldots$ & $\ldots$ \\
\hline$S \times D$ & 0.007 & 0.001 & $\ldots$ & $\ldots$ & $\ldots$ \\
\hline$S \times B$ & 0.006 & $\ldots$ & $\ldots$ & 0.005 & $\ldots$ \\
\hline$D \times B$ & $\cdots$ & $\cdots$ & $\cdots$ & $\ldots$ & $\cdots$ \\
\hline \multicolumn{6}{|c|}{ Three-way interactions } \\
\hline$T \times S \times D$ & $\ldots$ & $\ldots$ & $\ldots$ & $\ldots$ & $\ldots$ \\
\hline$T \times D \times B$ & $\ldots$ & $\ldots$ & $\ldots$ & $\ldots$ & $\ldots$ \\
\hline$T \times S \times B$ & 0.090 & $\ldots$ & $\ldots$ & $\ldots$ & $\ldots$ \\
\hline$S \times D \times B$ & $\ldots$ & $\cdots$ & $\cdots$ & $\ldots$ & $\cdots$ \\
\hline
\end{tabular}

Note: Four-way repeated-measures ANOVA on plants surviving the whole season: main and interaction effects for treatment $(T)$, size class $(S)$, and sampling date $(D)$ in three blocks per treatment $(B)$; no four-way interaction occurred.

not surprisingly, the number of leaves per plant varied within the season $(P<0.001)$. The greater number of leaves per plant was established in the insecticide treatment during the second half of the growing season: between 23 June 1995 and 18 August 1995, on both large- and small-sized plants (Table 2). The only significant interaction was between size and date $(P<$ 0.001 ). A lack of difference in the number of leaves per rosette at the end of the season is explained, in part, by seasonal leaf phenology. For both treatments, the number of leaves per plant was highest early in the season (2-9 May 1995), and declined until late Juneearly July. The numbers of leaves were lowest in midseason, 2.1 and 2.5 per small rosette and 2.7 and 3.9 per large rosette in water and insecticide treatments (Table 2). Leaf mortality was greatest in midseason (mid-June-late July) in both size classes, and similar between treatments (Table 2). These results suggest that, surprisingly, insect herbivory had less direct effect on leaf longevity than did physical conditions.

Rosette basal diameter was significantly larger for insecticide-treated than for control plants (Table 1; Treatment $F_{1,293}=17.73$ ), throughout the growing season and at its end (Fig. 4). Among large rosettes, the insecticide-treated plants averaged $37.5 \%$ larger in basal diameter than did the control plants, throughout the season (Fig. 4B). Among the small rosettes, insecticide-treated plants averaged $33.3 \%$ larger than the con- 

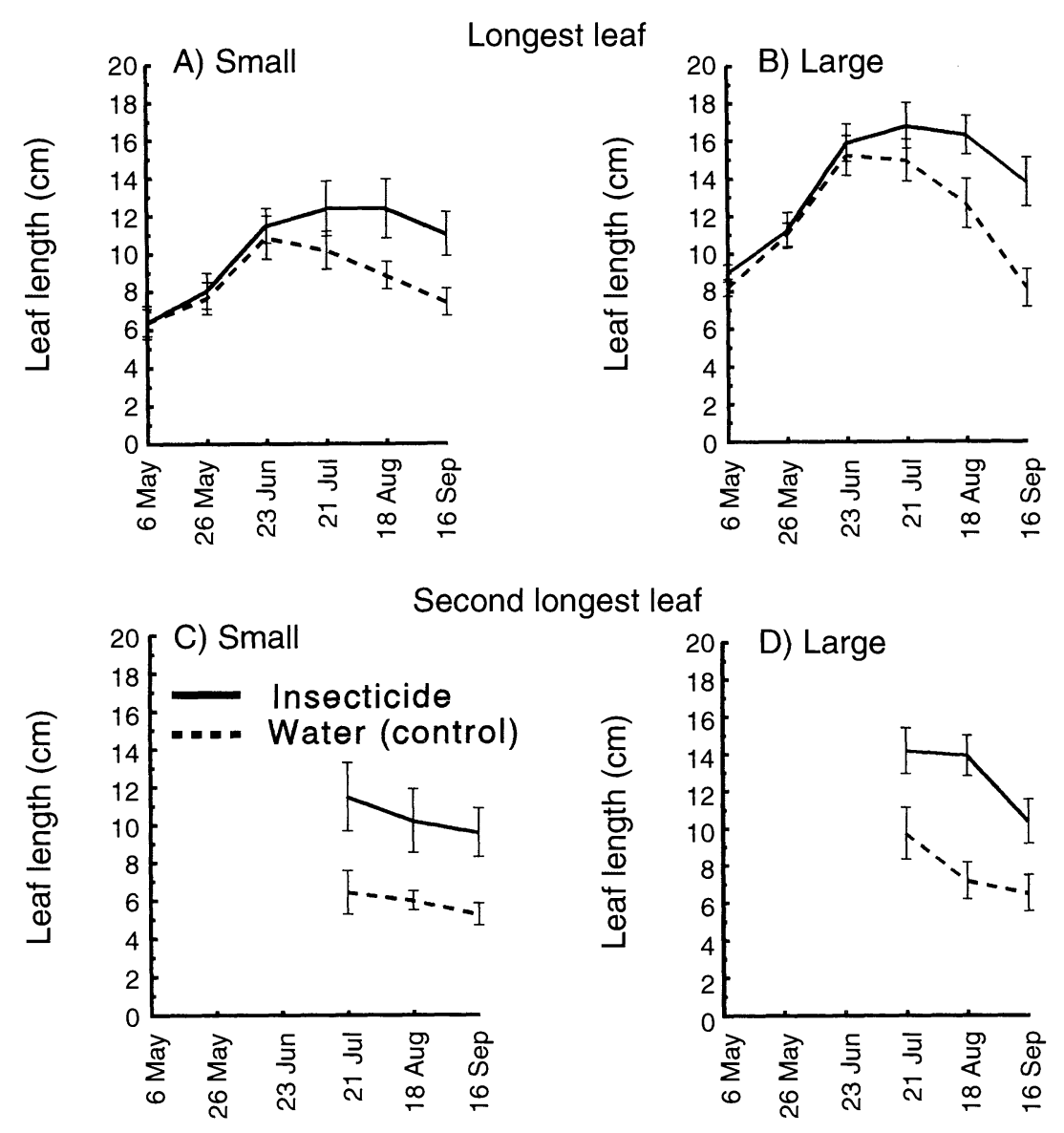

FIG. 3. Mean $( \pm 1 \mathrm{SE})$ leaf length representing growth response in insecticide and water-only treatments, by leaf length for both small $(<4.0 \mathrm{~mm}$ initial basal diameter) and large $(\geq 4.0 \mathrm{~mm}$ initial basal diameter) rosettes of tall thistle (Cirsium altissimum) on each sampling date in 1995: (A) longest leaf on small rosettes, (B) longest leaf on large rosettes, (C) secondlongest leaf on small rosettes (added measurement, starting 21 July 1995), and (D) second-longest leaf on large rosettes (added measurement, starting 21 July 1995). Differences between treatments were significant (see Table 1).

trols by the end of the season (Fig. 4A), but this difference between treatments was not established until July. After late June, average rootcrown diameter of insecticide-treated rosettes in both size classes did not decline in parallel with that of the more damaged control rosettes (Fig. 4A). In addition to the treatment effect, we found both size and date significantly affected growth of the basal diameter (Size $F_{1,293}=88.55, P$ $<0.001$; date $F_{4,293}=2.80, P<0.026$ ), with some of the variation possibly due to block position within the field $(P<0.07)$. The only significant interactions observed were between size and date $(P<0.01)$, and size and block $(P<0.01)$. The interactions suggest that significant temporal and spatial variation occurred in rosette growth.

Basal rosette diameter as measured included lower leaf petioles of the rosette as well as rootcrown at the soil surface. Thus, the measure was partially influenced by the number of green leaves, which differed between treatments (Table 1). However, the relative contribution of leaf bases vs. rootcrown growth can be estimated, by using the data on the total number of leaves and by assuming that the leaf contribution was proportional to the number of leaves. In the small size class, insecticide-treated rosettes had $14.1 \%$ more leaves, leaving $19.2 \%$ of the $33.3 \%$ increase in basal diameter best explained as rootcrown growth. In the large size class, the insecticide-treated rosettes had $9.7 \%$ more leaves, leaving $27.8 \%$ of the $37.5 \%$ increase in rosette diameter best explained as rootcrown growth.

\section{DISCUSSION}

Although natural enemies can sometimes exert a strong influence on plant performance (see Crawley 1983,1989 , Louda 1989, 1995), critical information is lacking on the role of coevolved natural enemies, such as insects, in weed population dynamics. Yet the most basic premise of classical biological control of weeds is that the introduction of natural enemies will reestablish the population limitation that is exerted within the native range (DeBach and Rosen 1991, Harley and Forno 1992). Reestablishment of natural enemies is 
TABLE 2. Mean (with \pm 1 SE in parentheses) total number of leaves and number of leaves that died since the last sampling date, per rosette by date (1995), for juveniles of Cirsium altissimum, Lincoln, Nebraska. The first date was the initial, pretreatment sample.

\begin{tabular}{|c|c|c|c|c|c|c|}
\hline & 6 May & 26 May & 23 Jun & $21 \mathrm{Jul}$ & $18 \mathrm{Aug}$ & $16 \mathrm{Sep}$ \\
\hline \multicolumn{7}{|l|}{ Small rosettes } \\
\hline \multicolumn{7}{|l|}{ Total leaves $\dagger$} \\
\hline Insecticide & $\begin{array}{c}5.1 \\
(0.44)\end{array}$ & $\begin{array}{c}3.4 \\
(0.34)\end{array}$ & $\begin{array}{c}2.5 \\
(0.22)\end{array}$ & $\begin{array}{c}2.6 \\
(0.33)\end{array}$ & $\begin{array}{c}3.0 \\
(0.33)\end{array}$ & $\begin{array}{c}3.1 \\
(0.27)\end{array}$ \\
\hline Water (control) & $\begin{array}{l}5.1 \\
(0.70)\end{array}$ & $\begin{array}{c}3.4 \\
(0.40)\end{array}$ & $\begin{array}{c}2.5 \\
(0.12)\end{array}$ & $\begin{array}{l}2.1 \\
(0.16)\end{array}$ & $\begin{array}{c}2.6 \\
(0.18)\end{array}$ & $\begin{array}{l}2.7 \\
(0.20)\end{array}$ \\
\hline \multicolumn{7}{|c|}{ Dead leaves, since previous date } \\
\hline Insecticide & $\begin{array}{c}0.6 \\
(0.18)\end{array}$ & $\begin{array}{c}1.2 \\
(0.22)\end{array}$ & $\begin{array}{l}2.4 \\
(0.22)\end{array}$ & $\begin{array}{c}2.0 \\
(0.22)\end{array}$ & $\begin{array}{c}0.7 \\
(0.19)\end{array}$ & $\begin{array}{c}0.8 \\
(0.19)\end{array}$ \\
\hline Water (control) & $\begin{array}{c}0.2 \\
(0.10)\end{array}$ & $\begin{array}{c}0.9 \\
(0.20)\end{array}$ & $\begin{array}{l}2.3 \\
(0.21)\end{array}$ & $\begin{array}{c}2.4 \\
(0.23)\end{array}$ & $\begin{array}{c}0.62 \\
(0.18)\end{array}$ & $\begin{array}{c}0.8 \\
(0.17)\end{array}$ \\
\hline \multicolumn{7}{|l|}{ Large rosettes } \\
\hline \multicolumn{7}{|l|}{ Total leaves $\dagger$} \\
\hline Insecticide & $\begin{array}{l}9.6 \\
(0.81)\end{array}$ & $\begin{array}{c}7.1 \\
(0.81)\end{array}$ & $\begin{array}{c}3.9 \\
(0.56)\end{array}$ & $\begin{array}{c}4.2 \\
(0.64)\end{array}$ & $\begin{array}{c}4.1 \\
(0.29)\end{array}$ & $\begin{array}{c}3.3 \\
(0.36)\end{array}$ \\
\hline Water (control) & $\begin{array}{l}10.1 \\
(0.46)\end{array}$ & $\begin{array}{c}6.9 \\
(0.62)\end{array}$ & $\begin{array}{c}3.1 \\
(0.28)\end{array}$ & $\begin{array}{c}2.7 \\
(0.32)\end{array}$ & $\begin{array}{c}3.1 \\
(0.27)\end{array}$ & $\begin{array}{c}3.0 \\
(0.34)\end{array}$ \\
\hline \multicolumn{7}{|c|}{ Dead leaves, since previous date } \\
\hline Insecticide & $\begin{array}{l}0.7 \\
(0.20)\end{array}$ & $\begin{array}{c}1.9 \\
(0.27)\end{array}$ & $\begin{array}{c}3.7 \\
(0.31)\end{array}$ & $\begin{array}{c}3.4 \\
(0.34)\end{array}$ & $\begin{array}{c}1.2 \\
(0.41)\end{array}$ & $\begin{array}{l}1.5 \\
(0.19)\end{array}$ \\
\hline Water (control) & $\begin{array}{c}0.6 \\
(0.17)\end{array}$ & $\begin{array}{c}2.0 \\
(0.28)\end{array}$ & $\begin{array}{c}3.7 \\
(0.22)\end{array}$ & $\begin{array}{c}3.4 \\
(0.25)\end{array}$ & $\begin{array}{c}0.7 \\
(0.27)\end{array}$ & $\begin{array}{c}1.2 \\
(0.20)\end{array}$ \\
\hline
\end{tabular}

$\dagger$ Four-way repeated measures ANOVA of the number of leaves per rosette for $(1)$ Main effects: treatment $\left(F_{1,293}=7.17\right.$, $P=0.008)$; size class $\left(F_{1,293}=35.96, P<0.001\right)$; sample date $\left(F_{4,293}=13.94, P<0.001\right)$; and block $\left(F_{2,293}=1.06, P=\right.$ 0.35). (2) Two-way interactions: treatment $\times \operatorname{size}\left(F_{1,293}=2.07, P \stackrel{P}{=} 0.15\right)$; treatment $\times$ date $\left(F_{4.293}=0.54, P=0.71\right)$; treatment $\times$ block $\left(F_{2,293}=0.55, P=0.58\right)$; size $\times$ date $\left(F_{4,293}=5.93, P<0.001\right)$; size $\times$ block $\left(F_{2,293}=0.21, P=0.81\right)$; date $\times$ block $\left(F_{8,293}=0.51, P=0.85\right)$. (3) Three-way interactions: treatment $\times$ size $\times$ date $\left(F_{4,293}=0.56, P=0.70\right)$; treatment $\times$ date $\times$ block $\left(F_{8,293}=0.66, P=0.72\right)$; treatment $\times$ size $\times$ block $\left(F_{2,293}=1.88, P=0.15\right)$; size $\times$ date $\times$ block $\left(F_{8,293}=0.10, P=0.99\right)$; and (4) Four-way interaction $\left(F_{8,293}=0.62, P=0.76\right)$.

$\$$ Four-way repeated-measures ANOVA of the number of leaves dying since the last sample date for all plants that survived throughout the experiment $(N=16$ and 14 small rosettes, and 13 and 17 large rosettes; in water-control and insecticide treatments, respectively). (1) Main effects: treatment $\left(F_{1,293}=0.42, P=0.52\right)$; size class $\left.\left(F_{1,293}\right)=37.44, P<0.001\right)$; sample date $\left(F_{4,293}=39.28, P<0.001\right)$; and block $\left(F_{2,293}=2.20, P=0.11\right)$. (2) Two-way interactions: treatment $\times$ size $\left(F_{1,293}=0.34, P=0.56\right.$, treatment $\times$ date $\left(F_{4.293}=0.61, P=0.65\right)$; treatment $\times$ block $\left(F_{2,293}=0.83, P=0.44\right) ;$ size $\times$ date $\left(F_{4,293}=1.18, P=0.32\right)$; size $\times$ block $\left(F_{2,293}=1.10, P=0.33\right)$; date $\times$ block $\left(F_{8,293}=1.15, P=0.33\right)$. (3) Threeway interactions: treatment $\times$ size $\times$ date $\left(F_{4,293}=0.60, P=0.66\right)$; treatment $\times$ date $\times$ block $\left(F_{8.293}=0.48, P=0.87\right)$; treatment $\times$ size $\times$ block $\left(F_{2,293}=0.30, P=0.74\right)$; size $\times$ date $\times$ block $\left(F_{8,293}=0.42, P=0.91\right)$. (4) Four-way interaction $\left(F_{8,293}=0.71, P=0.68\right)$.

expected to reduce fitness and densities of an alien weed, preventing it from acting as a economic pest within its new range. However, experimental data that establishes the extent to which individual survival and population growth of weeds are limited by natural enemies within their native range are sparse. Furthermore, a major gap exists in our understanding of the impact of insects during the early phases of the weed life cycle.

In our study, we tested the central hypothesis underlying efforts in the biological control of thistles: that insects can and do limit their survival and growth. Insecticide treatment reduced insect feeding significantly (Figs. 1 and 2), especially on larger rosettes. Reduction in herbivory led to significant increases in the survival of large rosettes and in the growth of both sizes of juveniles of this thistle within its native range (Figs. 3 and 4). One hypothesis that could explain the greater effect of insects on large rosettes is that herbivory on smaller plants is more variable than on large ones, lead- ing to a more consistent insect herbivore pressure on the larger juveniles.

The highly significant reduction in rootcrown diameter associated with insect feeding (Fig. 4) is particularly important to projection of the influence of insects on thistle population dynamics and density. In fact, simulation models (Doak 1992, Ehrlen 1995b) suggest that population growth of short-lived herbaceous perennials can be depressed more by vegetative damage than by seed losses. Ehrlen (1995b) found that the population growth rate of a legume was most sensitive to changes in the probability of individuals increasing in size. In addition, the diameter of the rootcrown is an index of plant size. Since flower number and seed production are usually correlated with plant size (Harper 1977, Fenner 1992), insect feeding on the rosettes may indirectly reduce seed production. Both direct and indirect reductions in seed production can decrease population growth and the density of poten- 

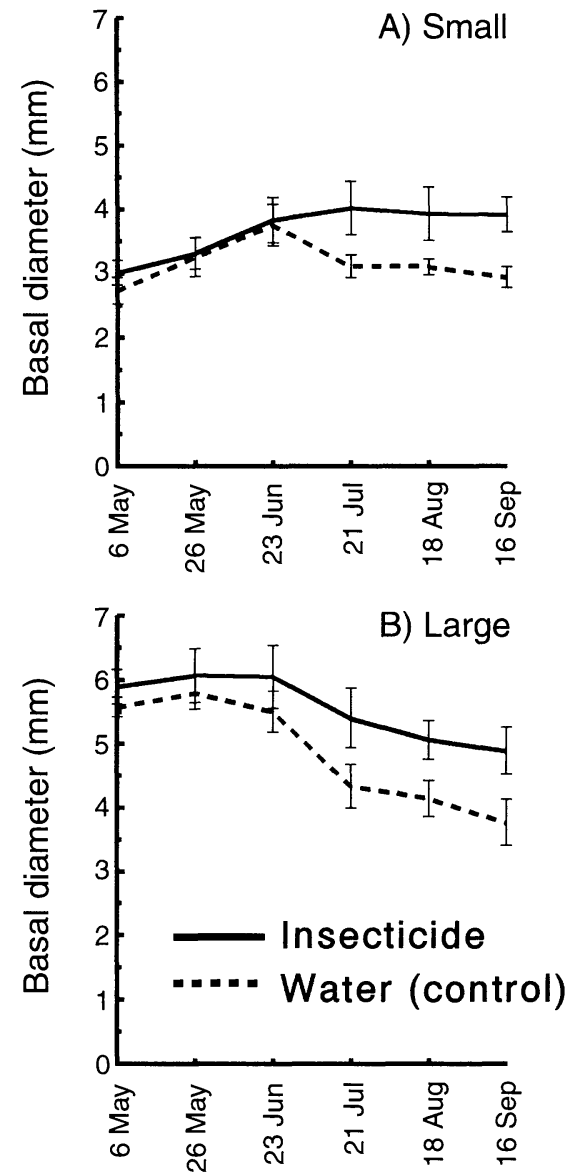

FIG. 4. Mean ( $\pm 1 \mathrm{SE})$ rosette basal diameter for rosettes of tall thistle (Cirsium altissimum) surviving over the 1995 season by treatment: (A) small, new rosettes $(<4.0 \mathrm{~mm}$ initial basal diameter; $N_{\mathrm{I}}=19, N_{\mathrm{C}}=17$ ); and (B) large, older rosettes ( $\geq 4.0 \mathrm{~mm}$ initial basal diameter; $N_{\mathrm{I}}=21, N_{\mathrm{C}}=23$ ). Differences between treatments were significant (see Table $1)$.

tially weedy plants (Louda 1995), including thistles such as these that depend on early successional or disturbed habitat for persistence (Louda et al. 1990, Louda and Potvin 1995).

Compensatory plant growth can sometimes mitigate or reverse the negative effects of tissue loss for adults (van der Meijden et al. 1988, Whitham et al. 1991). However, its significance in plant abundance and density under field conditions has been challenged (Verkaar 1988, Bergelson and Crawley 1992, Belsky et al. 1993). In this study, we found no evidence that compensatory growth eliminated or reversed the negative effects of insect feeding. Three responses are possible: complete compensation, overcompensation, and incomplete or no compensation for loss. Evidence for complete compensation would be the lack of a difference between treatments. However, we found large differences between treatments (Fig. 3, Tables 1 and 2). Also, the control plants, sprayed only with water and subjected to ambient levels of insect feeding, had significantly higher mortality, at least in the large size class, and lower growth rates than did insecticide-treated plants (Figs. 3 and 4).

Evidence of overcompensation would be greater rootcrown or leaf growth in the presence of insect herbivory, i.e., by the control plants. However, we clearly found the opposite (Figs. 3 and 4). The only other possible compensatory response is incomplete or no regrowth. Our experimental design would not have detected incomplete compensation. However, the occurrence of partial compensatory regrowth in response to herbivory would not have altered the main outcome, that rosette survival and net growth were reduced by insect feeding (Fig. 3). Any partial regrowth response would only decrease the magnitude of the difference between treatments. Actually, the results for leaf mortality (Table 2), together with those for the total number of leaves ( Tables 1 and 3), contradict the hypothesis that leaf-feeding by insects stimulated even partial compensatory regrowth by this thistle. The average number of leaves dying per month was similar in both treatments (Table 1), and the total number of leaves on insecticide-treated plants was higher on average than on control plants (Table 1). Together, these results suggest that insect feeding not only reduced leaf growth, but also reduced the rate of initiation of new leaves (as in Louda 1984), the opposite of the expected outcome if compensatory regrowth had occurred.

The results of this study are consistent with the relatively few previous studies that have experimentally determined the consequences of insect feeding on young stages in natural populations of short-lived, herbaceous perennial plants (Whittaker 1982, Mills 1984, Brown et al. 1988, Mills and Kummerow 1989). The general pattern emerging from these studies is that insect feeding on juveniles of herbaceous plants can be significant in reducing plants' survival and growth under the usual growing conditions.

In summary, the answers to the four questions we posed support the basic premise of classical biological weed control. Insect natural enemies played an important role in limiting weed performance within the native range. First, insects feeding on tall thistle rosettes under natural conditions removed $8.8 \%$ of leaf area from small rosettes and $21 \%$ from large rosettes on average over a season; they inflicted a significant amount of feeding damage to rosettes (Fig. 2) and to important leaves (Fig. 1). Second, insect feeding on rosettes decreased the survival of larger rosettes, the growth rate of leaves (Fig. 1), and seasonal increment in rootcrown size (Fig. 2) for both size classes (Table 1). Third, the intensity and impact of insect feeding were greater on the larger rosettes (Table 1, Figs. 1 and 2). Insect impact was not limited to large rosettes, however, since we found no significant interaction between treatment and size in any of the 'growth parameters measured (Table 1). Fourth, there was no evidence that compensatory 
regrowth counteracted the negative' effects of feeding damage by insects.

Finally, it was clear that it was the suite of herbivorous insects, rather than any one species, that led to cumulative leaf loss, lower survival, and subsequently to slower growth with potentially lower reproduction. Thus, our experimental data demonstrate that the guild of insect natural enemies limits the survival and reduces the growth of juveniles of this potentially weedy thistle within its native range. By documenting the negative effect of the leaf-feeding suite of natural enemies under natural conditions, the results support the rationale of biological weed control, especially with multiple complementary natural enemies.

\section{ACKNOWLEDGMENTS}

We appreciate receiving permission from the Lincoln Electric System, and especially the cooperation of Dick Scaggs, in allowing and facilitating our research on the grounds of the Wagner Substation. This work was supported by the National Science Foundation (DEB 92-21065) and the Research Council, University of Nebraska, for research on the effects of insects on native thistles; and by the Howard Hughes Memorial Institute in a grant to the School of Biological Sciences for a summer research scholarship for J. A. Guretzky. We appreciate the help of the following individuals in these areas: identification of insects by Brent Ratcliffe and Charles O'Brien, field assistance from and discussions with Rob Bevill, Amy Hines, Shannon McNeil, and Lynn Stanforth, and additional important discussions with David Mortensen and Brent Nickol.

\section{Literature Cited}

Belsky, A. J., W. P. Carson, C. L. Jensen, and G. A. Fox. 1993. Overcompensation by plants: herbivore optimization or red herring? Evolutionary Ecology 7:109-121.

Bergelson, J., and M. J. Crawley. 1992. Herbivory and Ipomopsis aggregata: the disadvantages of being eaten. American Naturalist 139:870-882.

Blossey, B. 1995. Host specificity screening of insect biological weed control agents as part of an environmental risk assessment. Pages 84-89 in H. M. T. Hokkanen and J. M. Lynch, editors. Biological control: benefits and risks. Cambridge University Press, Cambridge, UK.

Brown, V. K., M. Jepsen, and C. W. D. Gibson. 1988. Insect herbivory: effect on early old field succession, demonstrated by chemical exclusion methods. Oikos 52:293-302.

Crawley, M. J. 1983. Herbivory: the dynamics of animalplant interactions. University of California Press, Berkeley, California, USA.

- 1988. Herbivores and plant population dynamics. Pages 367-392 in A. J. Davy, M. J. Hutchings, and A. R. Watkinson, editors. Plant population ecology. Blackwell Scientific Publications, Oxford, UK.

- 1989. Insect herbivores and plant population dynamics. Annual Review of Entomology 34:531-564.

DeBach, P., and D. Rosen. 1991. Biological control by natural enemies. Cambridge University Press, Cambridge, UK.

Doak, D. F. 1992. Lifetime impacts of herbivory for a perennial plant. Ecology 73:2086-2099.

Ehrlen, J. 1995a. Demography of the perennial herb Lathyrus vernus. I. Herbivory and individual plant performance. Journal of Ecology 83:287-295.

- $1995 \mathrm{~b}$. Demography of the perennial herb Lathyrus vernus. II. Herbivory and population dynamics. Journal of Ecology 83:297-308.

Fenner, M., editor. 1992. Seeds: the ecology of regeneration in plant communities. CAB International, London, UK.
Forsyth, S. F., and A. K. Watson. 1985. Stress inflicted by organisms on Canada thistle. Pages 425-431 in E. S. Delfosse, editor. Proceedings, VI International Symposium on Biological Control of Weeds. Agriculture Canada, Ottawa, Canada.

Fye, R. E. 1982. Damage to vegetable and forage seedlings by the pale legume bug (Hemiptera: Miridae). Journal of Economic Entomology 75:994-996.

Great Plains Flora Association. 1986. Flora of the Great Plains. University Press of Kansas, Lawrence, Kansas, USA.

Harley, K. L. S., and I. W. Forno. 1992. Biological control of weeds. A handbook for practitioners and students. Inkata Press, Butterworths Proprietary, Melbourne, New South Wales, Australia.

Harper, J. L. 1977. The population biology of plants. Academic Press, New York, New York, USA.

Hendrix, S. D. 1988. Herbivory and its impact on plant reproduction. Pages 246-263 in J. Lovett Doust and L. Lovett Doust, editors. Plant reproductive ecology. Oxford University Press, Oxford, UK.

Lamp, W. O., and M. K. McCarty. 1979. A preliminary study of seed predators of Platte thistle. Transactions of the Nebraska Academy of Sciences 7:71-74.

Lamp, W. O., and M. K. McCarty. 1982. Predispersal seed predation of a native thistle, Cirsium canescens. Environmental Entomology 11:847-851.

Louda, S. M. 1982a. Distribution ecology: variation in plant recruitment in relation to insect seed predation. Ecological Monographs 52:25-41.

- 1982b. Limitation of the recruitment of the shrub Haplopappus squarrosus (Asteraceae) by flower- and seedfeeding insects. Journal of Ecology 70:43-53.

-1983. Seed predation and seedling mortality in the recruitment of a shrub, Haplopappus venetus (Asteraceae), along a climatic gradient. Ecology 64:511-521.

. 1984. Herbivore effect on stature, fruiting, and leaf dynamics of a native crucifer. Ecology 65:1379-1386.

. 1989. Predation in the dynamics of seed regeneration. Pages 25-51 in M. A. Leck, V. T. Parker, and R. L. Simpson, editors. Ecology of soil seed banks. Academic Press, New York, New York, USA.

1995. Effect of seed predation on plant regeneration: evidence from Pacific Basin Mediterranean scrub communities. Pages 311-344 in M. T. K. Arroyo, P. H. Zedler, and M. D. Fox, editors. Ecology and biogeography of Mediterranean ecosystems in Chile, California, and Australia. Springer-Verlag, New York, New York, USA.

Louda, S. M., and R. Masters. 1993. Biological control of weeds in Great Plains rangelands. Great Plains Research 3:167-199.

Louda, S. M., and M. A. Potvin. 1995. Effect of inflorescence-feeding insects in the demography and lifetime fitness of a native plant. Ecology 76:229-245.

Louda, S. M., M. A. Potvin, and S. K. Collinge. 1990. Predispersal seed predation, postdispersal seed predation, and competition in the recruitment of seedlings of a native thistle in sandhills prairie. American Midland Naturalist 124: 105-113.

Louda, S. M., and J. E. Rodman. 1996. Insect herbivory as a major factor in the shade distribution of a native crucifer (Cardamine cordifolia A. Gray, bittercress). Journal of Ecology 84:229-237.

Matches, A. G. 1992. Plant response to grazing: a review. Journal of Production Agriculture 5:1-7.

McEvoy, P., C. Cox, and E. Coombs. 1991. Successful biological control of ragwort, Senecio jacobaea, by introduced insects in Oregon. Ecological Applications 1:430442.

McEvoy, P. B., N. T. Rudd, C. S. Cox, and M. Huso. 1993. 
Disturbance, competition, and herbivory effects on ragwort Senecio jacabaea populations. Ecological Monographs 63: 55-75.

Meyer, G. A., and R. B. Root. 1993. Effects of herbivorous insects and soil fertility on the reproduction of goldenrod. Ecology 74:1117-1128.

Mills, J. N. 1984. Effects of feeding by mealybugs (Planococcus citri, Homoptera: Pseudococcidae) on the growth of Colliguaya odorifera seedlings. Oecologia 64:142-144.

Mills, J. N., and J. Kummerow. 1989. Herbivores, seed predators, and chaparral succession. Pages $49-55$ in S. C. Keeley, editor. The California chaparral: paradigms revisited. Natural History Museum of Los Angeles County, Los Angeles, California, USA.

Myers, J. H., C. Risley, and R. Eng. 1990. The ability of plants to compensate for insect attack: why biological control of weeds with insects is so difficult. Pages 65-71 in E. S. Delfosse, editor. Proceedings of the VII International Symposium on Biological Control of Weeds. Istituto Sperimentale per la Patologia Vegetale, Ministero dell'Agricoltura e delle Foreste, Rome, Italy.

Prins, A. H., H. J. Verkaar, and A. van den Herik. 1989. Responses of Cynoglossum officinale L. and Senecio jacobaea $\mathrm{L}$. to various degrees of defoliation. New Phytologist 111:725-731.

Rausher, M. D., and P. P. Feeny. 1980. Herbivory, plant density, and plant reproductive success: the effect of Battus philenor on Aristolochia reticulata. Ecology 61:905-917.

van der Meijden, E., W. Marijke, and H. J. Verkaar. 1988. Defense and regrowth, alternative plant strategies in the struggle against herbivores. Oikos 51:355-363.
Verkaar, H. J. 1988. Are defoliators beneficial for their host plants in terrestrial ecosystems?-a review. Acta Botanica Neerlandica 37:137-152.

Waloff, N., and O. W. Richards. 1977. The effect of insect fauna on growth, mortality, and natality of broom, Sarothamnus scoparius. Journal of Applied Ecology 14:787789.

Weis, A. E., and M. R. Berenbaum. 1989. Herbivorous insects and green plants. Pages 123-162 in W. G. Abrahamson, editor. Plant-animal interactions. McGraw-Hill, New York, New York, USA.

Whitham, T. G., J. Maschinski, K. C. Larson, and K. N. Paige. 1991. Plant responses to herbivory: the continuum from negative to positive and underlying physiological mechanisms. Pages 227-256 in P. W. Price, T. M. Lewinsohn, G. W. Fernandes, and W. W. Benson, editors. Plant-animal interactions: evolutionary ecology in tropical and temperate regions. John Wiley and Sons, New York, New York, USA.

Whitham, T. G., and S. Mopper. 1985. Chronic herbivory: impacts on architecture and sex expression of pinyon pine. Science 228: 1089-1091.

Whittaker, J. B. 1982. The effect of grazing by a chrysomelid beetle, Gastrophysa viridula, on growth and survival of Rumex crispus on a shingle bank. Journal of Ecology 70: 291-296.

Wilkinson, L. 1986. SYSTAT, the system for statistics. SYSTAT, Evanston, Illinois, USA.

Zammit, C. A., and M. A. Westoby. 1988. Predispersal seed losses, and the survival of seeds and seedlings of two serotinous Banksia shrubs in burnt and unburnt heath. Journal of Ecology 76:200-214. 